( Gi rask respons på artikler gjennom artikkelens kommentarfelt på tidsskriftet.no. Respons som er postet innen én måned etter at artikkelen er publisert, vurderes for publisering som Brev til redaktøren i papirutgaven.

Redaksjonen forbeholder seg retten til å foreta redaksjonelle endringer.

Forfattere av vitenskapelige artikler har tilsvarsrett, jf. Vancouver-gruppens regler.

\section{Blodtrykksbehandling - mot enighet om mangt}

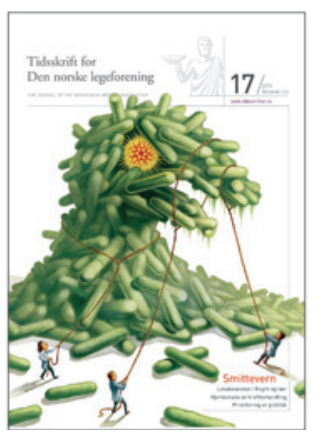

Bjørn Gjelsvik har en saklig omtale av våre artikler om blodtrykksbehandling $(1$, 2) på lederplass i Tidsskriftet nr. 17/2013 (3), men vi tillater oss å komme med noen presiseringer som vi kanskje også kan bli enige om.

Vi omtalte kun studier som hadde individuell statistisk styrke, nemlig LIFE, VALUE, ASCOT og ACCOMPLISH, alle studier med et større antall norske pasienter inkludert. Den nordamerikanske ALLHAT-studien hadde dessverre fire behandlingsarmer og manglet derfor statistisk styrke og ble avbrutt pga. «futility», dvs. ingen mulighet til å kunne vise forskjell mellom behandlingsgruppene, inklusive gruppen som fikk diuretika (4). Tiaziddiuretika var «taperen» i ACCOMPLISH-studien. Men for all del, tiaziddiuretika er viktig i blodtrykksbehandling, typisk i en kombinasjon med ARB, ACEI eller CCB. Alle studiene inkluderte pasienter med moderat til høy risiko.

Vedrørende sommerens diskusjon i Aftenposten har vi presisert (5) slik vi gjorde i arbeidet for Helsedirektoratet, publisert av oss i 2009 (6), at folk med mild hypertensjon (typisk blodtrykk $140-160 / 90-100 \mathrm{mmHg}$ ) som er aktuelle for primærprofylakse, bør undersøkes med tanke på organskade i hjerte, nyrer og store arterier, eventuelt med supplerende hjemmeblodtrykksmåling eller 24-timers blodtrykksmåling, for å bedømme risikoen. Påvises organskade eller hvis dagblodtrykket er $\geq 135 / 85 \mathrm{mmHg}$, er risikoen høy.

Vedrørende pasienter $>80$ år med høyt blodtrykk, har det vært kjent lenge at hjerneslag og hjertesvikt forebygges. Det nye med verdens største studie av gamle, nemlig HYVET ( $n=3845)$, organisert fra Cochrane-basens hjemborg London, er at det er trygt å behandle høyt blodtrykk ettersom dødeligheten også reduseres (7). Dette betyr mye for ellers friske 80 -åringer som forventes å leve atskillig lenger enn ni år, som er gjennomsnittet for alle. Det er ikke flere slike studier «på gang», verken i Norge eller utlandet.

\section{Sverre E. Kjeldsen \\ s.e.kjeldsen@medisin.uio.no \\ Marcus Schultz \\ Kristian Vinkenes \\ Tonje Amb Aksnes \\ Aud Høieggen}

Sverre E. Kjeldsen (f. 1953) er professor og seksjonsoverlege ved Hjertemedisinsk avdeling, Oslo universitetssykehus, Ullevål.

Oppgitte interessekonflikter: Han har mottatt konsultasjonshonorar/ forskningsstøtte/foredragshonorar fra Bayer, Medtronic, Serodus,

Takeda, AstraZeneca, Pronova, MSD.

Marcus Schultz (f. 1984) er student ved Det medisinske fakultet, Universitetet i Oslo.

Ingen oppgitte interessekonflikter

Kristian Vinkenes (f. 1980) er student ved Det medisinske fakultet, Universitetet i Oslo.

Ingen oppgitte interessekonflikter.
Tonje Amb Aksnes (f. 1973) overlege ved Hjertemedisinsk avdeling, Akershus universitetssykehus.

Oppgitte interessekonflikter: Hun har mottatt foredragshonorar/reisestøtte fra AstraZeneca, MSD, Novartis og Pfizer.

Aud Høieggen (f. 1956) er førsteamanuensis og seksjonsoverlege ved Nyremedisinsk avdeling, Oslo universitetssykehus, Ullevål.

Oppgitte interessekonflikter: Hun har mottatt foredragshonorar fra AstraZeneca, Novartis, Amgen og St. Jude Medical.

\section{Litteratur}

1. Schultz M, Aksnes TA, Høieggen A et al. Medikamentvalg ved hypertensjon. Tidsskr Nor Legeforen 2013; 133: 1802-3.

2. Vinkenes K, Kjeldsen SE. Hypertensjon hos friske over 80 år bør behandles. Tidsskr Nor Legeforen 2013; 133: 1804-5.

3. Gjelsvik B. Blodtrykksbehandling - kilde til debatt. Tidsskr Nor Legeforen 2013; 133: 1792

4. McInnes GT, Kjeldsen SE. Never mind the quality, feel the width-ALLHAT revisited. Blood Press 2004; 13: 330-4.

5. Kjeldsen SE, Sirnes PA. Høyt blodtrykk må ikke bagatelliseres. Det kan drepe. Aftenposten 4.8.2013.

6. Norheim OF, Gjelsvik B, Kjeldsen SE et al. Nasjonale retningslinjer for individuell primærforebygging av hjerte- og karsykdommer. Oslo: Helsedirektoratet 2009 .

7. Beckett NS, Peters R, Fletcher AE et al. Treatment of hypertension in patients 80 years of age or older. N Engl J Med 2008; 358: 1887-98.

Dette er en redigert versjon av debatten, publisert som rask respons på nett 8.10.2013. http://tidsskriftet.no/article/3058042/

\section{B. Gjelsvik svarer:}

Jeg må konstatere at vi nok ikke blir enige om bedømmelsen av ALLHAT-studien. Studien var eksepsjonelt stor og viste at klortalidon (i doser 12,5-25 mg) var minst like effektivt til å forebygge død av hjerte- og karsykdom og hjerteinfarkt som kalsiumblokkere og ACE-hemmere. Senere metaanalyser og Cochrane-rapporter har underbygget dette $(1,2)$. Lavdose tiazider er trygt, effektivt til å forebygge død av hjerte- og karsykdom og svært kostnadseffektivt, og det er ingen grunn til å endre retningslinjene i Norge på dette punktet. Skal noe endres, bør det heller være i retning av at lavdose tiazider som oftest bør være førstevalget ved ukomplisert hypertensjon, slik det var for noen år tilbake.

Når det gjelder behandling av høyt blodtrykk hos friske 80åringer, er jeg enig $i$ at behandling kan forebygge slag og død av hjerte- og karsykdom. Men «bottom line» er om total dødelighet reduseres, og der har litteraturen vært sprikende, selv om den altså var positiv i HYVET-studien. Selv om studien viste effekt, var det for de fleste av endepunktene grensesignifikante funn og store konfidensintervaller (3). For øvrig er det verdt å merke seg at et lavdose tiazidliknende diuretikum (indapamid) var studiemedikamentet i HYVET-studien. Det er ikke sikkert at andre medikamenter er like trygge. I tillegg har tiazider en fordel ved at de forebygger osteoporose. Hos eldre kvinner kan det være en viktig tilleggsindikasjon.

Det er mange kliniske utfordringer i denne aldersgruppen, slik at resultatene fra HYVET-studien ikke uten videre kan overføres til klinisk praksis. Spørsmålet om hvilket blodtrykksnivå der behandling bør starte, og hvordan vi skal forholde oss til isolert systolisk hypertensjon, er ikke besvart. Det er viktig å monitorere blodtrykket nøye før man starter behandling, for eksempel om blodtrykket faller etter måltid, om det foreligger ortostatisme, eller om det er høyt på natten. Hos de eldste er det vanskeligere å predikere nytten 